\title{
Formalization of Guarantees of Human and Civil Rights and Freedoms in the Constitutions of the Commonwealth of Independent States

\author{
${ }^{1}$ Lyudmila O. Losilkina, ${ }^{2}$ Alevtina E. Novikova, ${ }^{3}$ Azamat M. Shadzhe, ${ }^{4}$ Lyudmila A. Tkhabisimova, ${ }^{5}$ Vassiliy \\ A. Zajcev \\ 1,2 Belgorod State University, 85, Pobedy Street, Belgorod, The Belgorod Region, 308015, Russia \\ ${ }^{3}$ Adyghe State University, 208, Pervomayskaya str., Maikop, 385000, Russia \\ ${ }^{4}$ Pyatigorsk State University, 9, Kalinin Ave, Stavropol region, Pyatigorsk, 357532, Russia \\ ${ }^{5}$ Belgorod Law Institute of MIA of Russia named after I. D. Putilin, 71 Gorky St., Belgorod, 308024, Russia \\ Email: novikova_a@bsu.edu.ru
}

\section{Received: 22 ${ }^{\text {nd }}$ June 2018, Accepted: 01 ${ }^{\text {st }}$ August 2018, Published: 31 ${ }^{\text {st }}$ August 2018}

\begin{abstract}
The paper presents the results of a comparative legal study of the constitutional norms of the Commonwealth of independent States member States in order to identify provisions that provide guarantees of human and civil rights and freedoms. The authors identify the universal and special formulations of the sought guarantees and the classification of provisions associated with guarantees of rights and freedoms of the individual, as well as the subjects of their implementation on the basis of the given criteria.
\end{abstract}

Keywords: Guarantees, State Guarantees, Judicial Protection, Society, Rights and Freedoms of Man and Citizen.

\section{Introduction}

In the most general content form, the guarantees of human and citizen's rights and freedoms are presented in theory by a system of conditions, means and methods that provide for all and everyone with equal legal opportunities to identify, acquire and realize their rights and freedoms [1, p. 32-25]. We believe that guarantees are one of the main components of the legal mechanism for the implementation of legal rights, and in our view the constitutional formalization of guarantees is the basic vector to minimizing human rights risks.

Within the framework of this study, foreign constitutions of member countries of the Commonwealth of Independent States are subject to comparative legal analysis due to the commonality of a certain stage of their historical development [2, p. 352-356], as well as replenishment of the doctrinal provisions of the human rights risks theory $[3, \mathrm{p} .151-$ 157].

\section{Methodology}

The research was based on a dialectical approach to the disclosure of legal phenomena and processes using also general scientific (systematic, logical, analysis and synthesis) and specific scientific approaches. Among the latter there were formal-legal, linguistic3682 legal, and comparative-legal, which were collectively used to identify the regulations governing the duties of an individual. The focus group was composed of 6 countries that are members of the Commonwealth of Independent States, the texts of their constitutions were taken from the Internet library of the "Constitution of the states (countries) of the world" (http://worldconstitutions.ru/) [4].

\section{Discussion and Results}

An analysis of the constitutions of the declared group of states has shown that in most of them the provisions of a universal character that determine the guaranteeing role of the state in relation to a person, his/her rights and freedoms are enshrined.

So in chapter II, article 26 of the Azerbaijani Constitution everyone is guaranteed with protection of their rights and freedoms by the state.

The meaningfully broader is the wording of Article 2 from the Constitution of Belarus. According to this article a person, his/her rights, freedoms and guarantees for their implementation are the supreme value and purpose of society and the state. Thus, the constituted guarantor is not only the state, but society as well.

The state is the guarantor of not any group of individual rights and freedoms, but only those that are enshrined in the Constitution and laws, and are provided for by the state's international obligations (art. 21 of the Constitution of Belarus).

Similar to the presented one is the wording of Part 1, Article 12 from the Constitution of the Republic of Kazakhstan with the only proviso that human rights and freedoms are recognized and guaranteed only in accordance with the Constitution.

Attention is drawn to the approach according to which the guarantees of personality are formalized in combination with the principle of non-discrimination. For example, according to Article 17 of the Tajikistan Constitution, the state guarantees the rights and freedoms of everyone irrespective of their nationality, race, sex, language, religion, political opinions, education, social and property status. This experience 
is also reflected in the Azerbaijani Constitution (p. III, Article 25).

In our opinion, the provisions of the Constitution of the Republic of Moldova are interesting. It contains a standard version of the provision according to which rights and freedoms are guaranteed (Part 3 of Art. 1). Also part 2 of Article 142 of the Constitution establishes inadmissibility of the revision of the Constitution, the consequence of which would be abolition of not only the fundamental rights and freedoms of citizens, but also their guarantees. We would like to clarify that this kind of situation exists only in the Constitution of Moldova, and it deserves a positive assessment, thereby emphasizing the importance of the institution of legal guarantees for the state.

In connection with the fact that, in addition to universal provisions, a state is the key subject of guaranteeing the rights and freedoms of an individual, there are widely spread wordings in constitutions on guarantees implemented by state bodies - state representatives. The most numerous are the provisions on judicial guarantees. They are set out as an opportunity to appeal to judiciary and as the specifics of their implementation at various stages of the process.

So, chapter I, Article 60 of the Constitution of Azerbaijan guarantees the protection of the rights and freedoms of everyone in court.

Chapter VIII, Article 127 of the Constitution of the same state contains the provision that the right to protection at any stage of the proceedings is guaranteed to everyone.

Chapter X, Article 127 of the Constitution of Azerbaijan provides that persons who are participants in the judicial proceedings and do not know the language in which the proceedings are carried out, have been guaranteed with the right to fully acquaint themselves with the case materials, participate in court with the help of an interpreter, and speak in court in their native language.

It should be noted that the guarantee norms of Article 127 of the Azerbaijan Constitution can be viewed on the one hand as judicial guarantees, but on the other hand are state guarantees of various types of subjective individual rights. This clarification is also valid for similar formulations included in other constitutions Tajikistan and Uzbekistan. In the first of them, everyone has been guaranteed with judicial protection (Article 19) and legal assistance at all stages of the investigation and court proceedings (Article 92). The state also guarantees judicial protection to a victim and compensation for the damage caused to them (Article 21).

In Article 44 of the Constitution of Uzbekistan, everyone has the guarantees of judicial protection of his/her rights and freedoms, as well as the right to appeal to the court against illegal actions of state bodies, officials, and public associations.

Article 116 of the Constitution of Uzbekistan specifies the guarantee of the right to professional legal assistance at any stage of the proceedings.

Article 60 of the Constitution of Belarus provides that everyone has the guarantee on protection of his/her rights and freedoms by a competent, independent and impartial court within the time limits established by law.

Part 1 of Article 40 of the Constitution of Kyrgyzstan states that everyone has the right for guaranteed judicial protection of his/her rights and freedoms, and further specifies the types of these rights (stipulated by the Constitution, laws, international treaties, generally recognized principles and norms of international law). The wording of Part 4 of Article 29 in the Constitution of Kyrgyzstan is of our interest: according to the part, everyone has guarantees of protection, including judicial protection, from improper collection, storage and dissemination of confidential information and information about their private life; the right to compensation for material and moral damage caused by unlawful actions is guaranteed as well. We believe that special pointing at judicial protection as guarantees of these rights is due to the fact that they are associated with a personal nature and, thus, their importance is emphasized in comparison with others. As classical, we consider the formulations of constitutions in accordance with which the head of state (the president, in these cases) is the guarantor of the rights and freedoms of an individual and citizen, (Article 79 in Belarus, Part 2, Article 40 in Kazakhstan, Article 64 in Tajikistan, and Article 93 in Uzbekistan).

Let us clarify that in the constitutions of the CIS countries the declared guarantees of the rights and freedoms of man and citizen are for the most part formalized without a certain order. Although, for the sake of justice it should be noted that Article 53 of the Constitution of Azerbaijan is called "Guarantee of the right to citizenship" and Chapter $\mathrm{X}$ of the Constitution of Uzbekistan is called "Guarantees of human rights and freedoms". However, this fact is not decisive in determining the effectiveness of constitutional norms on guarantees of human and civil rights and freedoms. Further we notice that as a result of the analysis carried out, the group of the constitutional norms was revealed, by which guarantees of the rights and freedom of the person are determined without indication of the subject of guarantee. We can draw conclusions about this from the context of the norms. So, it can be the employer and in chapter II, Article 37 of the Azerbaijani Constitution, workers under an employment contract have statutorily guaranteed but 
not exceeding eight hours daily working day, rest days and holidays, and paid leave of at least twenty-one calendar days at least once a year.

The remaining formulations are related to guaranteeing separate rights or freedoms to:

- Artistic, scientific, technical creativity and teaching (Article 51 of the Constitution of Belarus, part 1 of Article 20 of the Constitution of Kazakhstan, part 1 of Article 49 of the Constitution of Kyrgyzstan, Part 1 of Article 33 of the Constitution of Moldova, art. 42 of the Constitution of Uzbekistan);

- Inviolability of the home and other legal possessions of citizens (Article 29 of the Constitution of Belarus); - Opinions, beliefs and their free expression (Article 33 of the Constitution of Belarus, part 1 of Article 32 of the Constitution of Moldova, art. 30 of the Constitution of Tajikistan);

- Receipt, storage and dissemination of complete, reliable and timely information on the activities of state bodies, public associations, on political, economic, cultural and international life, and the state of the environment (Article 34 of the Constitution of Belarus, part 4, Article 33 of the Constitution of Kyrgyzstan);

- To work, to choose a profession, occupation and work in accordance with vocation, abilities, education, vocational training taking into account social needs, as well as healthy and safe working conditions; training in new specialties and upgrading skills in the light of social needs, as well as unemployment benefits (Article 41 of the Constitution of Belarus); for negotiations on labor issues and the obligation of collective agreements (Part 4, Article 43 of the Constitution of Moldova). Substantially similar are the statements of Part 4, Article 24 of the Constitution of Kazakhstan ;

- On health protection (part 1, Article 36 of the Constitution of Moldova), including free treatment in public health institutions (Article 45 of the Constitution of Belarus, part 2, Article 29 of the Constitution of Kazakhstan);

- For social security in old age, in case of illness, disability, loss of ability to work, loss of breadwinner and in other cases provided for by law (Article 47 of the Constitution of Belarus); on the minimum wage and pensions, social security by age, in case of illness, disability, loss of breadwinner and other legal grounds (Part 1, Article 28 of the Constitution of Kazakhstan). Similar are the statements of Part 1, Article 53 of the Constitution of Kyrgyzstan, and article 39 of the Constitution of Tajikistan;

- On free secondary education in public educational institutions (part 1, Article 30 of the Constitution of Kazakhstan), accessible and free general secondary and vocational education (Article 49 of the Constitution of Belarus);
- Of conscience (Part 1, Article 31 of the Constitution of Moldova, Article 31 of the Constitution of Uzbekistan) and religion (Part 1, Article 32 of the Constitution of Kyrgyzstan);

- Movement around the country (Part 1, Article 27 of the Constitution of Moldova);

- Inheritance of private property (Part 6, Article 46 of the Constitution of Moldova);

Part 1, Article 26 of the Constitution of Moldova laconically guarantees the right to protection.

We emphasize that in relation to the presented types of legal rights and freedoms, guarantees are provided without their association exclusively with the state. Such guarantors can be state and public structures of undivided authority and collective varieties.

We believe that it is appropriate to list the types of legal rights and freedoms that are guaranteed by the state in constitutional norms:

- The right to inherit (Part V, Article 29 of the Constitution of Azerbaijan);

- The right of everyone to preserve the secrecy of correspondence, telephone conversations, postal, telegraphic messages and information transmitted by other means of communication (Part IV, Article 32 of the Constitution of Azerbaijan);

- Free exercise of literary, artistic, scientific and technical and other forms of creativity (part II, Article 51 of the Constitution of Azerbaijan);

- Freedom to choose the language of education and training (Article 50 of the Constitution of Belarus);

- Equal opportunities for the free use of abilities and property for entrepreneurial (Part II, Article 15 of the Constitution of Azerbaijan) and other economic activities not prohibited by law (Article 13 of the Constitution of Belarus, article 12 of the Constitution of Tajikistan, article 53 of the Constitution of Uzbekistan). The Uzbek Constitution also formalizes in this norm the state guarantee of the right to work;

- Freedom of assembly, meetings, street processions, demonstrations and picketing (Article 35 of the Constitution of Belarus);

- Ownership (Part 2, Article 127 of the Constitution of Moldova) and assistance to its acquisition (Article 44 of the Constitution of Belarus), the right of private property, as well as debt obligations assumed by the state (Part 1, Article 46 of the Constitution of Moldova) ;

- Return of deposits (Article 44 of the Constitution of Belarus);

- Protection and auspices outside the state (Part III, Article 53 of the Constitution of Azerbaijan, article 10 of the Constitution of Belarus, Part 2, Article 11 of the Constitution of Kazakhstan, part 5, Article 50 of the Constitution of Kyrgyzstan, article 22 of the Constitution of Uzbekistan); 
- Free medical care, as well as medical care on preferential terms (part 3, Article 47 of the Constitution of Kyrgyzstan);

- The right of all citizens to preserve, develop and express ethnic, cultural, linguistic and religious identity (part 2, Article 10 of the Constitution of Moldova);

- The right to life and to physical and mental integrity (Part 1, Article 24 of the Constitution of Moldova, article 18 of the Constitution of Tajikistan);

- The right to free access to reliable information on the state of the natural environment, living and working conditions, the quality of food and household items, and on its distribution (Part 2, Article 37 of the Constitution of Moldova);

- Access to free general secondary, secondary vocational and, in accordance with abilities and on a competitive basis, secondary specialized and higher education (article 41 of the Constitution of Tajikistan) in the state educational institutions. Only access to free general education is stated in Article 41 of the Constitution of Uzbekistan, and free compulsory general secondary education in Part II, Article 42 of the Constitution of Azerbaijan. In Part IV, Article 42 of the said Constitution, the state guarantees the continuation of education for talented individuals regardless of their financial situation.

In the investigated group of constitutional norms, those in which legal rights or personal freedoms are guaranteed not by the state but by the law were found; they are:

- The right to vote, equality and freedom of expression (article 117 of the Constitution of Uzbekistan), to be elected (Part 3, Article 38 of the Constitution of Moldova);

- The secret of bank deposits and the right to inherit (Article 36 of the Constitution of Uzbekistan);

- The right to property, including the right of inheritance (Part 2, Article 26 of the Constitution of Kazakhstan).

It should be noted that when formulating the norms on guaranteeing rights and freedoms in the CIS constitutions, they are typically associated with "everybody" or "citizen". At the same time, in the focus group of constitutions, norms - guarantees relating to special subjects have been identified. Among them are:

- workers with the right to take part in the management of enterprises, organizations and institutions in order to increase the efficiency of their work and improve the socio-economic standard of living (Article 13 of the Constitution of Belarus).

- youth with the right to its spiritual, moral and physical development, as well as creation of conditions on the part of the state for free and effective participation of young people in political, social, economic and cultural development (Article 32 of the Constitution of Belarus);

- Representatives of all ethnic groups forming the people of Kyrgyzstan with the right to preserve their native language, creating conditions for its study and development (Part 3, Article 10 of the Constitution of Kyrgyzstan).

\section{Conclusions}

In the constitutions of the CIS member states, provisions for the guarantees of human and civil rights and freedoms are presented without a specific system. The key guarantor of legal rights is the state and, in this regard, universal norms are included in almost all the constitutions of the focus group. Numerous are the norms - guarantees addressed to the head of state and the judicial branch of power. In general, at the constitutional level, a state guarantees various types of legal rights and freedoms. At the same time, their diverse catalog is also guaranteed by non-state actors. In addition to the standard languages that guarantee the rights of everyone or citizens, special recipients (for example, workers, youth, ethnic groups, etc.) are identified.

\section{References}

1. Lupenko I.YU. Constitutional guarantees of justice in the system of guarantees of rights and freedoms of man and citizen // State power and local self-government. 2015. № 1. S. 32-35. (In Russian)

2. Kornyushkina A.Y., Markhgeym M.V., Novikova A.E., Doronina O.N., Zajcev S.Y. Minimization of human rights risks: the constitutional legal experience of post-soviet states // The Turkish Online Journal of Design, Art and Communication TOJDAC. 2017. April. Special Edition. P. 352-356.

3. Novikova A.E. The concept and essence of human rights risks // Scientific statements. BelGU. Series: Philosophy. Sociology. Law. 2011. № 14 (109). Issue 17. P. 151-157. (In Russian)

4. "Constitution of the states (countries) of the world" (http://worldconstitutions.ru/) 